\title{
Report of the \\ SEARO/WPRO/IMMLEP/THELEP Joint Scientific Meeting on Leprosy Rangoon, Burma, 18-19 November 1981*
}

A scientific meeting on the chemotherapy and immunology of leprosy was held, 18-19 November 1981, at the Department of Medical Research of the Ministry of Health of Burma in Rangoon, jointly sponsored by the South-East Asian and Western Pacific Regional Offices of the World Health Organization, and the Immunology of Leprosy (IMMLEP) and Chemotherapy of Leprosy (THELEP) Scientific Working Groups of the UNDP/World Bank/WHO Special Programme for Research and Training in Tropical Diseases. Those participating were:

Dr M Abe, National Institute for Leprosy Research, Tokyo, Japan, Dr A B Adiga, Ministry of Health, Pachali, Nepal,

Dr Anan C Pakdi, SEARO, New Delhi, India,

Dr Aung Win Thien, Department of Medical Research, Rangoon, Burma,

Dr Ayele Belehu, Armauer Hansen Research Institute, Addis Ababa, Ethiopia,

Dr Bencha Petchclai, Ramathibodi Hospital, Bangkok, Thailand,

Dr V N Bhatia, Central Leprosy Teaching and Research Institute, Chingleput, South India,

Dr B R Bloom, Albert Einstein College of Medicine, Bronx, New York, USA,

Dr C J G Chacko, Schieffelin Leprosy Research and Training Centre, Karigiri, South India,

Dr S Chan, National University of Singapore, Singapore,

Dr M C Christian, Schieffelin Leprosy Research and Training Centre, Karigiri, South India,

Dr J Convit, Instituto Nacional de Dermatologia, Caracas, Venezuela,

Dr E Daulako, Twomey Memorial Hospital, Suva, Fiji,

Dr K V Desikan, Central JALMA Institute for Leprosy, Agra, India,

Dr G A Ellard, National Institute for Medical Research, London, England,

Dr C A P Ferracci, Institut Marchoux, Bamako, Mali,

Dr P Fine, London School of Hygiene and Tropical Medicine, London, England,

Dr T Godal, Norwegian Radium Hospital, Oslo, Norway,

Dr G le Gonidec, Institut Pasteur, Noumea, New Caledonia,

* In addition to this report, 5 papers presented at the Rangoon meeting appear in this issue of Leprosy Review. It is our understanding that this report, together with other papers presented at the meeting, will appear in a forthcoming issue of the International Journal of Leprosy. EDITOR. 
Dr R S Guinto, Leonard Wood Memorial, Cebu, Philippines,

Dr J Guld, Copenhagen, Denmark,

Dr Huan Ying Li, Beijing Friendship Hospital, Beijing, China,

Dr Ji Baohong, Zeng Yi Hospital, Shanghai, China,

Dr Kinh Due, Hôpital Bach Mai, Hanoi, Vietnam,

Dr Kyaw Lwin, Ministry of Health, Rangoon, Burma,

Dr L Levy, Hebrew University-Hadassah Medical School, Jerusalem, Israel,

Dr L Lopez-Bravo, WPRO,

Daw Mar Mar Nyein, Department of Medical Research, Rangoon, Burma,

Dr Maung Maung Ghi, Department of Health, Mandalay, Burma,

Dr P N Neelan, Central Leprosy Teaching and Research Institute, Chingleput, South India,

Dr S K Noordeen, World Health Organization, Geneva, Switzerland,

Dr S R Pattyn, Prince Leopold Institute for Tropical Medicine, Antwerp, Belgium,

Dr J M H Pearson, Dhoolpet Leprosy Research Centre, Hyderabad, India,

Dr M Pinto, University of Sri Lanka, Peradeniya, Sri Lanka,

Dr K Rajagopalan, National Leprosy Control Centre, Sungei Buloh, Malaysia,

Dr R J W Rees, National Institute for Medical Research, London, England,

Dr N M Samuel, Anadaban Hospital, Kathmandu, Nepal,

Dr H Sansarricq, World Health Organization, Geneva, Switzerland,

Dr P S Seshadri, Central Leprosy Teaching and Research Institute, Chingleput, South India,

Dr J K Seydel, Borstel Research Institute, Borstel, Federal Republic of Germany,

Dr C C Shepard, Centers for Disease Control, Atlanta, Georgia, USA,

Dr G P Talwar, All-India Institute of Medical Sciences, New Delhi, India,

Dr Than Win, Department of Health, Rangoon, Burma,

Dr R Utji, University of Indonesia, Jakarta, Indonesia,

Dr Vicharn Vithayasai, Chiang Mai University, Chiang Mai, Thailand,

Dr M F R Waters, Hospital for Tropical Diseases, London, England,

Dr Ye Gan Yun, Chinese Academy of Medical Sciences, Taizhou, China,

Dr Y Yuasa, Sasakawa Memorial Health Foundation, Tokyo, Japan.

The meeting was opened with welcoming speeches by Dr Kyaw Lwin, Deputy Director (Leprosy), Department of Health, Ministry of Health of Burma, Dr Aung Than Batu, Director, Department of Medical Research, Dr H Sansarricq, Chief Medical Officer, Leprosy Unit, WHO, and Dr S Pattanayak, Acting WHO Programme Coordinator, Rangoon.

The first day was devoted to papers on the chemotherapy of leprosy. Dr L Levy described the goals of the THELEP programme, and the strategy that had been adopted to achieve these goals. This paper was followed by 2 papers devoted to the THELEP controlled clinical trials of the chemotherapy of lepromatous leprosy. Dr M F R Waters discussed the background of the trials, sketching the 
historical development of the concept of trials in which the attempt is made to detect 'persisting' Mycobacterium leprae by inoculation of immunosuppressed mice, and describing the design of the trials. Dr R J W Rees presented the available results from inoculation of mice, with particular emphasis on the unexpectedly high prevalence of primary resistance to dapsone in both the Central Leprosy Teaching and Research Institute, Chingleput, South India, and the Institut Marchoux, Bamako, Mali, sites of the current trials.

Dr S R Pattyn described the design of the THELEP field trials of chemotherapy of lepromatous leprosy, in which lepromatous patients are to be treated with largely intermittent, multidrug regimens for 2 years after achieving smear-negativity, after which chemotherapy will be stopped and the relapse rate measured. This paper was followed by a description of the SEARO-sponsored Burma Rifampicin Trial, presented by Dr Maung Maung Ghi. This latter trial involves an attempt to interrupt transmission of $M$. leprae from infectious source to contact by the addition of a brief (2-week) course of daily rifampicin to the standard dapsone monotherapy; the hoped for result is a decreased attack rate, compared to that in the control population in which only standard dapsone monotherapy is employed. Dr G A Ellard then discussed the problem of the generally poor compliance of leprosy patients with the prescribed therapy.

There followed 7 papers on various aspects of resistance to dapsone. Dr J M H Pearson presented the problem as it was understood at the time THELEP activities began, and described the strategies adopted by THELEP further to elucidate the problem. Dr M C Christian presented an up-date of the continuing prevalence survey of secondary dapsone resistance in Gudiyatham Taluk. Dr R S Guinto presented the results of the recently completed survey of primary resistance to dapsone in Cebu. Dr P N Neelan and Dr Kyaw Lwin described the on-going surveys of secondary resistance in, respectively, Trivellore Taluk, South India and Myingyan Township, Burma. Dr Ji Baohong presented the results of a virtually completed survey of secondary resistance in Shanghai Municipality. Finally, Dr Robert Utji presented the first results of an informal survey of dapsone resistance in Jakarta, including those of 1 patient with primary resistance.

The second day of the meeting was devoted to presentations on the immunology of leprosy. The research plans and progress of IMMLEP were summarized by Drs Bloom, Godal, Rees and Shepard. Dr Bloom spoke on the rationale for vaccination in leprosy, Dr Godal on immunological mechanisms in leprosy, Dr Rees on the production of $M$. leprae from armadillos, the IMMLEP Bank for M. leprae, and the purification procedures, and Dr Shepard on the animal vaccination studies with various preparations and on the animal models for immunological tolerance. This was followed by 3 papers on studies carried out on human beings with 'vaccine' preparations. Dr Convit presented his data on vaccinotherapy of a large number of lepromatous and borderline patients with a mixture of killed M. leprae and live BCG. Dr Bapat presented data on studies 
carried out by his group on patients using the ICRC bacillus. Dr Talwar presented data on human studies using Mycobacterium $W$ and also a preparation of hapten modified $M$. leprae. Following these, Dr Fine presented a paper on the epidemiology of leprosy, and Dr Noordeen spoke on epidemiological consideration in vaccine trials. The operational problems in vaccine trials were discussed by Dr Guld, particularly in relation to the BCG trial in South India. The formal presentations were followed by a Round Table on epidemiological studies in leprosy with Drs Maung Maung Ghi, Guinto, Ye, Samuel, Vicharn, Neelan, Christian and Noordeen participating. The discussion at the Round Table brought out the various field studies being carried out by scientists from the developing endemic countries and opportunities for their participation in the IMMLEP/THELEP supported activities. 